
Zakirov R.H., 2019

DOI 10.18019/1028-4427-2019-25-4-561-568

\title{
A comprehensive approach to the in vitro and in vivo study of a preparation containing etidronate of lanthanide and calcium ions
}

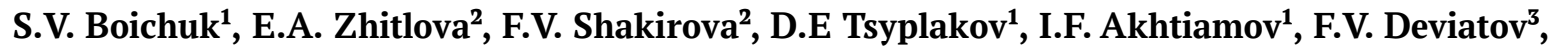 \\ B.R. Ramazanov ${ }^{1}$, R.H. Zakirov ${ }^{1}$
}

${ }^{1}$ Kazan State Medical University of the Ministry of Health of the Russian Federation,

${ }^{2}$ Kazan State Academy of Veterinary Medicine of the Ministry of Science and Education of the Russian Federation,

${ }^{3}$ Kazan Federal University of the Ministry of Science and Education of the Russian Federation

\begin{abstract}
The search for new more effective techniques to repair bone fractures and defects is an urgent task of healthcare. Objective To explore the efficacy of a preparation containing etidronates of lanthanide and calcium ions in regenerative repair of bone defects. Material and methods The osteoblastic MC3T3-E1 and the osteoclastic RAW 264.7 cell lines were used in in vitro experiments at the first stage of the research. The agent was postoperatively injected in a bone defect of 36 rabbits on days 3 and 5 to assess the preparation's effect on regenerative repair of small defects with diameter of $2.5 \mathrm{~mm}$. Radiometric and reactive morphological characteristics of bone tissue were evaluated at the fracture site at the beginning, middle and end of experiment. Results The above preparation was found to enhance osteogenic differentiation and stimulate accumulation of intracellular calcium in MC3T3 E1 cells. However, the preparation was not shown to inhibit RANKL-induced osteoclast differentiation in vitro. Histological and computed tomography findings demonstrated statistically significant differences between control and experimental animals $(\mathrm{p}<0.01)$ and indicated to the preparation's effect of promoting regenerative repair of small bone defects. Conclusion The series was the first to show the effect of the preparation containing etidronates of lanthanide and calcium ions as stimulating osteoblast activity in vitro and promoting early regenerative repair of small bone defects.
\end{abstract}

Keywords: lanthanide, etidronate, osteoblast, osteoclast, osteolysis, regeneration of bone defect

\section{INTRODUCTION}

The search for new more effective techniques to repair bone fractures and defects is an urgent task of healthcare [1]. Introduction of more effective agents stimulating bone regeneration is important to improve outcomes of an injury or a disease. The requirements the agents and preparations must meet include high biological activity and biocompatibility, osteogenic, osteoconductive, osteoinductive capacities; they must be biodegradable to be on a par with the rate of bone regeneration [2-6]. 1-Hydroethane-1, diphosphonic (etidronic) acids represent diphosphonates that are used as potassium and sodium salts (xydiphone, etodronate) in medicine for regulation of calcium metabolism in osteoporotic patients and pathological ossification through insoluble oxalates and calcium phosphates. The primarily ionic link type being typical for calcium ions and lanthanides and the proximity to Ahrens parameter $(\mathrm{P} \cdot \alpha=2.6-2.8 \mathrm{eV} \cdot \AA \AA 5 / 2)[7-9]$ are practical for lanthanide ions being injected as a complex to be incorporated in the structure of hydroxyapatite which is the basic mineral constituent of the osseous tissue. Early studies showed that lanthanides could suppress the development of cells (osteoclasts) being responsible for resorption of osseous tissue [10-13]. A combination of diphosphonates and lanthanides appeared to enhance synergic effect intensifying bone regeneration. The experimental work that supported the hypothesis indicated to accelerated bone regeneration at the fracture or defect site due to combined use of the elements reducing a period of recovery of physiological function of the injured bone $[14,15]$. The studies emerged as a base for synthesis of a new pharmaceutical containing the above composition conventionally named as INROK, staged exploration of its effect on in vitro osteoblast and osteoclast differentiation and its capability to improve in vivo bone regeneration.

Objective. The aim of the study was to explore in vitro osteoinductive properties of a preparation containing etidronates of lanthanide and calcium ions and assess the in vivo effect on reparative regeneration.

Doichuk S.V., Zhitlova E.A., Shakirova F.V., Tsyplakov D.E, Akhtiamov I.F., Deviatov F.V., Ramazanov B.R., Zakirov R.H. A comprehensive approach to the in vitro and in vivo study of a preparation containing etidronate of lanthanide and calcium ions. Genij Ortopedii, 2019, vol. 25, no 4, pp. 561-568. DOI 10.18019/1028-4427-2019-25-4-561-568. (In Russian) 


\section{MATERIAL AND METHODS}

Reactive chemicals. INROK is prepared using proportions [16-18] described in patents (RU 2248210, RU 2521344, EP2848250) (RU 2248210, RU 2521344, EP2848250) and contains etidronic acid, calcium chloride, gadolinium nitrate (III), dysprosium chloride (III) related as 50:75:4:1 with pH $7.4 \pm 0.1$. The studies showed that concentration of free (free from soluble and insoluble complexes) forms of etidronates, $\mathrm{Ca}^{2+}$ and $\mathrm{Ln}^{3+}\left(\mathrm{Gd}^{3+}+\mathrm{Dy}^{3+}\right)$ in INROK measured $4 \cdot 10^{-4}$ (orally administered xydiphone results in maximal concentration of $3 \cdot 10^{-4}$ in blood), $2 \cdot 10^{-4}$ (in blood $\sim 10^{-2}$ ) and $\sim 10^{-15} \mathrm{~mol} / \mathrm{L}$, correspondingly. In addition to that, the majority of the components are bound in sedimentary, partially soluble forms so that the preparation is a suspension with a particle size of about 6 microns ("Malvern" Zetasizer Nano ZS instrument). Therefore, insoluble substances are sort of a vessel providing, according to Le Chatelier's Principle, a constant, low (not exceeding the threshold of evident toxicity) concentration of active forms (etidronate and $\mathrm{Ln}^{3+}$ ) in the solution to be consumed during specific processes. The solution contains free sodium ions, chloride- and nitrate ions quantified as $5 \cdot 10^{-2}, 3 \cdot 10^{-2}$ and $2.5 \cdot 10^{-3} \mathrm{~mol} / \mathrm{L}$, correspondingly.

Cell lines and culturing. Macrophage cell line RAW 264.7 (ATCC, TIB-71) and pre-osteoblast cell line MC3T3-E1 (ATCC, CRL-2593) were purchased from American Tissue Culture Collection (ATCC, USA). RAW 264.7 cells were cultured in DMEM medium supplemented with $10 \%$ fetal bovine serum (FBS) and $1 \%$ penicillin/streptomycin, in a humidified atmosphere of $5 \% \mathrm{CO}_{2}$ (LamSystems, Russia) at $37^{\circ} \mathrm{C}$. MC3T3-E1 cells were cultured in T-75 flasks (Corning, USA) in Alpha Minimum Essential Medium supplemented with ribo- and desoxyribonucleotides, $2 \mathrm{mM}$ glutamine, $1 \mathrm{mM}$ sodium pyruvate (Gibco, USA), $10 \% \mathrm{FBS}$ and $1 \%$ antibiotics, in moist chamber at $37^{\circ} \mathrm{C}$ and in atmosphere of $5 \% \mathrm{CO}_{2}$ (LamSystems, Russia). Genistein (Sigma-Aldrich, USA) was used as a positive control to determine INROK's capacity inhibit osteoclast differentiation (TRAP test).

Analysis of cytotoxicity using MTS test. The above cell lines were cultured at 96-well plates (Corning, USA) for 24 hours and incubated with $1-20 \mu \mathrm{M}$ of INROK for the next three days. Culture supernatants were mixed with MTS reagent (Promega, USA) and incubated for 24 hours to assess viability of the cells using a microplate reader MultiScan (Thermo Fisher Scientific, USA) at the wavelength $492 \mathrm{~nm}$. The half maximal inhibitory concentration $\left(\mathrm{IC}_{50}\right)$ was determined at 48-72 hour incubation with the substance that suppressed viability of the cells by $50 \%$. The findings were normalized with the cells cultured in the solvent medium (control).

\section{Tartrate-Resistant Acid Phosphatase (TRAP)} staining (reliable method of identifying mature osteoclasts). The use of RAW264.7 cell line allowed a quality evaluation of the preparation being capable of inducing osteoclast differentiation. Leukocyte Acid Phosphatase assay kit (Sigma-Aldrich, USA) was used to demonstrate tartrate-resistant acid phosphatase. RAW264.7 cells were cultured in 12-well plates (Corning, USA) $3 \times 10^{4}$ cells per well in full DMEM medium supplemented with L-glutamine, antibiotics (all reagents from RANEKO, Russia) and $10 \%$ FBS (HyClone, USA). The next day of culturing the medium was replaced by the medium containing $50 \mathrm{ng} / \mathrm{mL}$ RANKL (R\&D Systems, USA) and INROK or genistein (Sigma-Aldrich, USA) used as a positive control. The experiments were carried out in triple replications replacing the medium every two days of culturing. The cell culture medium was removed from the plate after 5 days, the cell monolayer washed with ice-cold phosphate buffered saline (PBS) and fixed in $3.5 \%$ formalin for 10 minutes at room temperature. The cells were cleaned three times with distilled water and incubated with the above batch for 3 hours at $37^{\circ} \mathrm{C}$ according to manufacturer's recommendation. Mature osteoclasts were visualized with light microscopy in presence of multinucleated (containing three and more nuclei) TRAP-positive cells in 7 random fields of view in each of the experimental groups (control, cultured with genistein and INROK).

Quantification of the TRAP activity. With the differentiation of RAW 264.7 cells into mature osteoclasts accomplished after 5-day culturing the culture medium supplemented with RANKL was removed, the cell monolayer washed twice with icecold PBS and fixed in $3.5 \%$ formalin for 10 minutes and then with ethanol and acetone (ratio 1:1) for 60 seconds. The samples were dried and incubated in reactive mixture containing $50-\mathrm{mM}$ citrate buffer 
(pH 4.5) supplemented with $10 \mathrm{mM}$ sodium tartrate and $6 \mathrm{mM}$ p-nitrophenylphosphate. After one-hour incubation the samples were placed in a 96-well plate containing equal volume of $\mathrm{NaOH}(0.1 \mathrm{~N})$. Quantification of tartrate-resistant acid phosphatase activity was produced with microplate reader MultiScan (Thermo Fisher Scientific, USA) at the wavelength $405 \mathrm{nM}$. TRAP activity was measured with regard to control (solvent) samples.

Determination of osteoblast activity in vitro (quality and quantitative reaction using Alizarin Red). The capability of INROK compound induce accumulation of calcium in osteoblasts was assessed with Alizarin Red stain. Murine pre-osteoblast MC3T3-E1 cells were cultured at 6-well plates $\left(1 \times 10^{5}\right.$ cells/well $)$ for 72 hours in atmosphere of $5 \% \mathrm{CO}_{2}$ and at $37^{\circ} \mathrm{C}$. Then the culture medium was replaced with Osteogenesis Induction \#1 medium and cultured for the next 6 days with the medium renewed every 2-3 days. The medium of MC 3T3-E1 cells cultured for 6 days was replaced with osteogenesis induction medium № 1 containing Alpha Minimum Essential Medium, 10 \% FBS, $0.2 \mathrm{mM}$ ascorbic acid 2-phosphate solution, $10 \mathrm{mM}$ glycerol Acid 2-Phosphate Solution that was replaced every 3 days. Six days later the medium was replaced by osteogenesis induction medium № 2 supplemented with melatonin (positive control). The cells were cultured with INROK cells and the solvent (control) in medium \# 1. Six-day culturing was followed by Alazarin Red staining to evaluate mineralization. MC3T3-E1 cells were washed twice with ice-cold PBS and fixed in $4 \%$ formalin and stained with $2 \%$ Alazarin Red ( $\mathrm{pH}$ 4.2). Then the cells were washed with PBS and visualized with light microscopy (Olympus BX 63, Japan). Quantification was produced with microplate reader MultiScan (Thermo Fisher Scientific, USA) at the wavelength $560 \mathrm{nM}$. The dye was extracted from the cell samples within 30 minutes using $10 \%$ ethanoic acid and culture supernatants were plated on 96-well plates.
In vivo experiments. Experiments were carried out on 36 outbred rabbits as a preclinical trial at the department of veterinary surgery according to GOST ISO 10993 (R) and approved by Local Ethic Board of the Kazan State Medical University (Protocol № 9 dtd November 25, 2014. Local injury to the medial surface of the proximal tibia was produced by drilling the cortical bone to form a blind cylindrical defect $3 \mathrm{~mm}$ in diameter [19]. The animals were subdivided into two groups. Control rabbits received no INROK injections in trauma site. Experimental animals received $0.2 \mathrm{ml}$ INROK locally injected in the cortical defect on postoperative days 3 and 5 . Experimental studies lasted for 56 days. Histological examinations of the marginal bone defect and the regenerate bone were performed on days 7, 14, 28 and 56. Morphometric parameters of the regenerate bone that filled the perforated hole included such structural components as granulation, connective and cartilaginous tissues; reticular fibrous and lamellar tissues; leukocytic and necrotic masses. The material collected was fixed in $10 \%$ neutral buffered formalin, decalcified, dehydrated and embedded in paraffin. Histological preparations (microtome sections of 5-7 $\mathrm{mcm}$ ) were stained with hematoxylin and eosin, and pyrofuxin using van Gieson method. Morphometric technique was applied to quantitatively assess the structures [20-21]. The calculations were produced in percentage from the total area of the histological section.

Computerized transverse axial scanning tomography was produced on postoperative days 7 , 28 and 56 using multispiral Brillance 64 computed tomograph (Philips). Multiplanar reconstruction (MPR) sagittal imaging of the regenerate bone was used for quantitative assessment of the cortical density at the defect site [22]. The defect was identified in interactive mode and the area was calculated in Hounsfield (HU) units. Statistical analysis was performed with SPSS Version 13.0 statistic software package using Student's t-test and Bonferroni correction. A value of $p<0.05$ was considered statistically significant.

\section{RESULTS}

INROK does not inhibit osteoclast differentiation from RAW 264.7 cells

RANKL/RANK-induced signaling pathways have been proven to play an important role in in vitro regulation of osteoclast functional activity. RANK- expression murine macrophage RAW 264.7 cell line was used to determine the effect of the study preparation on functional activity and differentiation of osteoclasts. RAW 264.7 cells were cultured in special medium for differentiation of osteoclasts 
(see Material and Methods for details) supplemented with FBS and RANKL (50 ng/mL). Then the TRAP staining was used to visualize mature multinucleated osteoclasts. Since the earlier tests showed evident inhibition activity of genistein in differentiation of osteoclasts [23-24] the compound was employed as a control at the stage of study. The RAW 264.7 cell line was shown to readily differentiate into osteoclasts upon exposure to RANKL (Fig. $1 \mathrm{a}, \mathrm{b}$ ). Multinucleated cells considerably decreased with genistein that proved its capability to inhibit differentiation of osteoclasts from RAW 264.7 cells with qualitative and quantitative tests (Fig. 1c, d, g). The effect of the compound was dose-dependent. The experiment showed that INROK did not inhibit osteoclast differentiation from RAW 264.7 cells (Fig. 1 e, f, g). Cytotoxicity MTS assay showed that the concentrations of $100-1000 \mu \mathrm{M}$ used for the compound did not result in death of RAW 264.7 cells and did not inhibit the division rate throughout the culturing period.

\section{INROK stimulates formation of osteoblasts from} MC3T3-E1 cells in vitro

Qualitative and quantitative methods with Alizarin Red staining were used to study capability of INROK induce bone mineralization. Cells incubated with melatonin were used as a positive control. We detected considerable increase in alizarin-positive cells in samples incubated with melatonin and INROK as compared to controls cultured in a special medium stimulating osteogenesis (Fig. $2 \mathrm{a}-\mathrm{g}$ ). A 0.5 and $1 \mathrm{mM}$ concentrations of INROK were found to have evident mineralizing effect as compared to melatonin. The findings were confirmed with qualitative analysis of calcium deposition (Fig. $2 \mathrm{f}$ ). Cytotoxicity MTS assay showed that a $100-1000 \mu \mathrm{M}$ concentrations of INROK did not result in death of MC3T3 cells and did not inhibit the division rate throughout the culturing period.
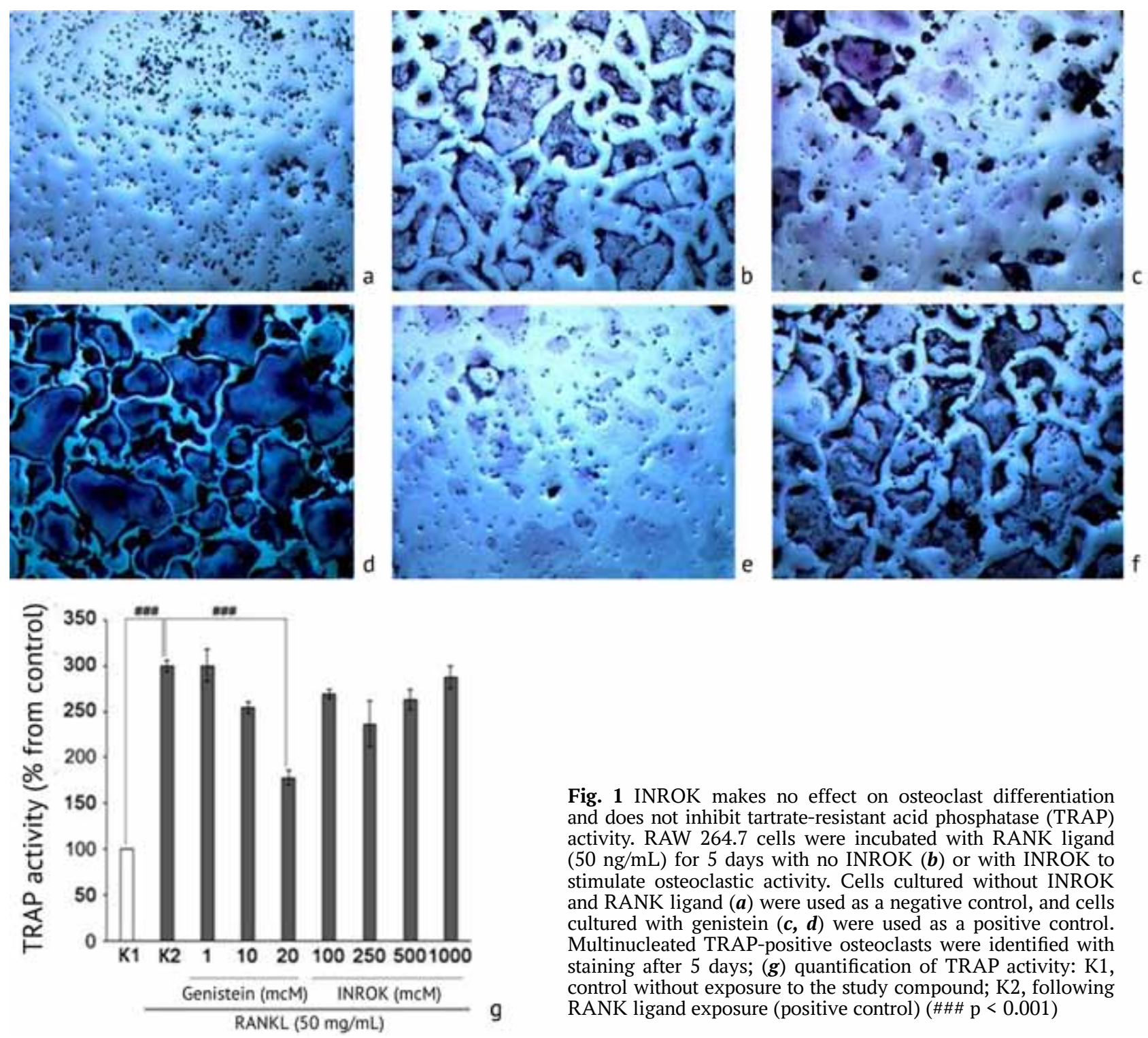

Fig. 1 INROK makes no effect on osteoclast differentiation and does not inhibit tartrate-resistant acid phosphatase (TRAP) activity. RAW 264.7 cells were incubated with RANK ligand $(50 \mathrm{ng} / \mathrm{mL})$ for 5 days with no INROK $(\boldsymbol{b})$ or with INROK to stimulate osteoclastic activity. Cells cultured without INROK and RANK ligand $(\boldsymbol{a})$ were used as a negative control, and cells cultured with genistein $(\boldsymbol{c}, \boldsymbol{d})$ were used as a positive control. Multinucleated TRAP-positive osteoclasts were identified with staining after 5 days; (g) quantification of TRAP activity: K1, control without exposure to the study compound; K2, following RANK ligand exposure (positive control) $(\# \# \# \mathrm{p}<0.001)$ 

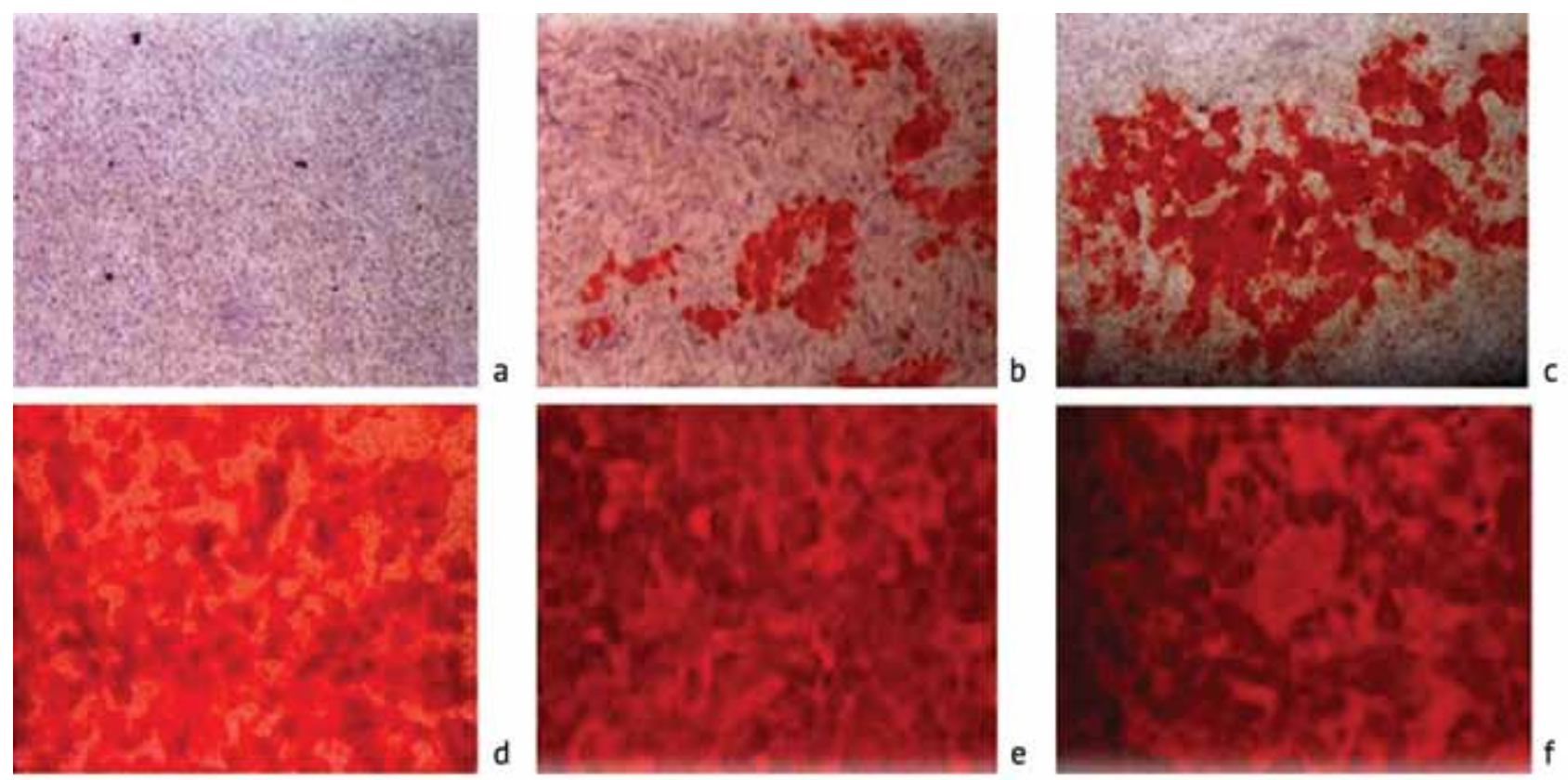

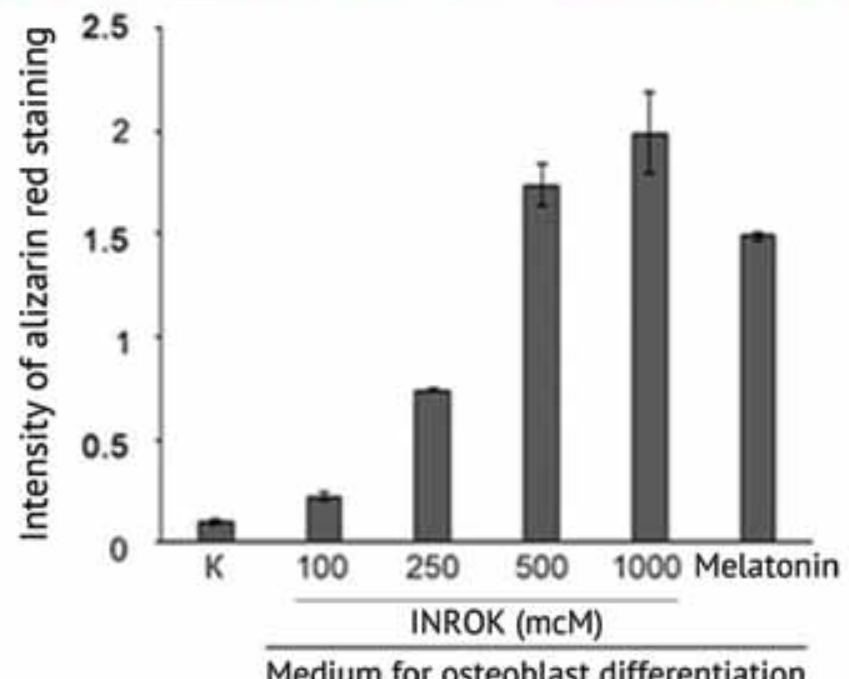

INROK stimulates in vivo healing of bone defects

Observation of experimental animals showed that the general condition, nutrimental irritability did not change throughout the experiment. Rabbits could well tolerate neuroleptanalgesia and surgical intervention. They could re-ambulate after 30-35 minutes with nutrimental irritability restored after 3-5 hours. Histological examination of bone tissue showed decreased inflammation in experimental animals after 7 days of observation as compared to controls $(5.5 \pm 0.8 \%$ and $14.6 \pm 1.4 \%$ ), and statistically significant decrease (nearly twofold) in the area of perforation $(27.6 \pm 2.1 \%$ and $15.9 \pm 1.4 \%)$. Regeneration normally started with proliferation of blood vessels and migration of fibroblasts. Mesenchymal elements located between vascular loops indicated to the formation of granulation that was shown to increase in experimental group by $16 \%(70.6 \pm 1.1 \%$ and $53.6 \pm 3.1 \%(\mathrm{p}<0.05)$, correspondingly). Controls
Fig. 2 INROK stimulates bone mineralization in MC3T3-E1 line cells. Calcium deposition can be visualized with alizarin red staining: $(\boldsymbol{a})$ cells with no exposure (negative control); $(f)$ cells exposed to melatonin (positive control); ( $\boldsymbol{c}-\boldsymbol{e})$ cells after exposure to INROK $(100-1000 \mathrm{mcM}) ;(g)$ quantitative analysis of the intensity of staining. Cells cultured without the supplement of INROK and melatonin were used as a control $(\mathrm{K})$

demonstrated signs of necrosis and calcification of bone tissue at edges of the defect (Fig. 3). No reparation was observed in control group at the time.

Granulation and connective tissue appeared to transform into cartilaginous tissue in controls after 14 postoperative days. An area of connective tissue measured $68.0 \pm 2.5 \%$ in experimental animals that was 1.5 times more than that in controls $(48.2 \pm 0.6 \%(p<0.05))$. Some cases of the group developed reticular fibrous tissue with trabeculae being linked to the edges of perforation. Reticular fibrous tissue showed threefold increase in the area $(18.2 \pm 0.6 \%, \mathrm{p}<0.05)$ as compared to controls $(6.0 \pm 1.0 \%)$. Bone defect closed in the majority of the cases. Enchondral osteogenesis was observed in singular cases. Inflammatory reaction next to reparation was either slightly manifested or absent (Fig. 3 c, d). 
Perforating hole was replaced with reticular fibrous tissue and diffused calcificated trabeculae at 28-day observation. Cartilaginous tissue was nearly absent and measured $4.0 \pm 0.9 \%$ in controls and $0.6 \pm 0.1 \%$ in experimental animals, and the bone marrow was filled with hematopoietic components spread over bone trabeculae (Fig. 3 e, f).

The bone completely and uneventfully healed in all the animals after 56 days of experiment. Lamellar bone $(98.8 \pm 0.2 \%)$ with extensive network of vascular channels, restored bone marrow and the surrounding sift tissues could be visualized at the site of perforation in experimental animals (Fig. $3 \mathrm{~g}, \mathrm{~h}$ ). The controls showed areas of necrosis and destruction

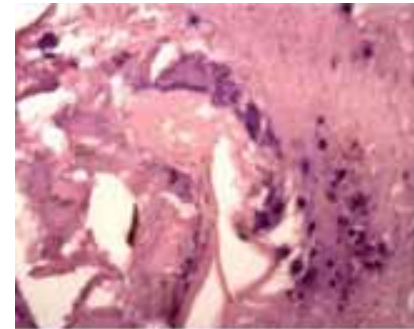

a

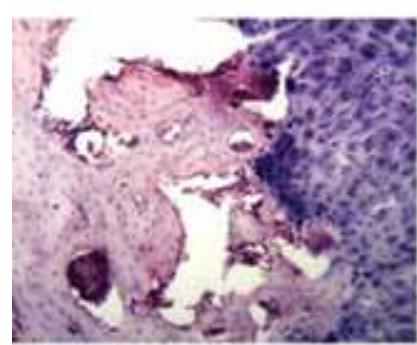

e

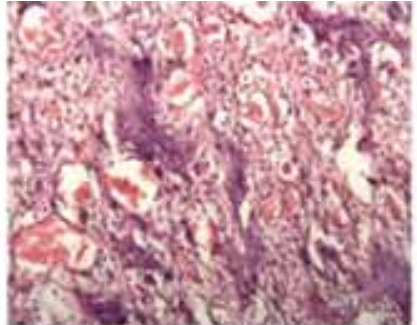

b

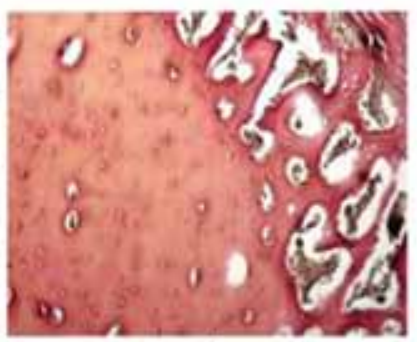

f

of cartilaginous tissue and the lamellar bone occupied $88 \%$ of the section $(88.7 \pm 0.6 \%)$.

Computed tomography (CT) densitometry findings

CT findings showed statistically significant $(p=0.001)$ increase in densitometry values of the regenerate bone in experimental animals at 7 days of experiment that was 2.5 fold as compared to those in controls $(916.6 \pm 26.5 \mathrm{HU}$ and $366.6 \pm 33.6 \mathrm{HU}$, correspondingly) (Fig. 4). The regenerate density measured $1120.6 \pm 27.1 \mathrm{HU}$ in experimental animals, increased $4 \%$ as compared to that in controls $(1078.2 \pm 57.4 \mathrm{HU})$ at the end of experiment.

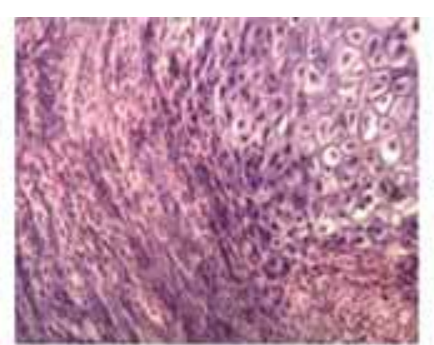

C

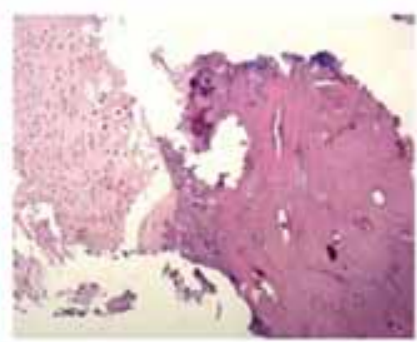

q

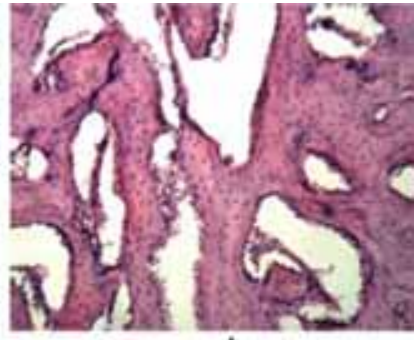

d

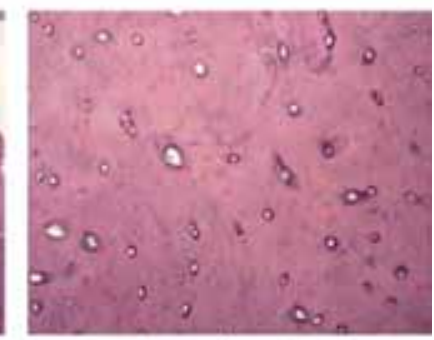

h

Fig. 3 Histological picture of bone tissue in control (to the left) and INROK animals (to the right). Stained with hematoxylin and eosin: $(\boldsymbol{a}, \boldsymbol{b})$, necrotic and decalcified bone tissue at the edges of perforation $(\boldsymbol{a})$, granulations $(\boldsymbol{b})$ observed at 7 days of experiment; $(\boldsymbol{c}, \boldsymbol{d})$ granulations and connective tissue transformed into cartilaginous tissue $(\boldsymbol{c})$ coarse fibrous tissue structured with trabeculae filling perforating hole $(\boldsymbol{d})$ seen at 7 days of experiment; $(\boldsymbol{e}, \boldsymbol{f})$ cartilaginous tissue transformed into coarse fibrous tissue $(\boldsymbol{e})$, coarse fibrous tissue restructured into lamellar bone $(\boldsymbol{f})$ at 28 days of experiment; $(\boldsymbol{g}, \boldsymbol{h})$ lamellar bone and cartilaginous fragments and necrotic foci $(\boldsymbol{g})$ and the formed system of Haversian canals $(\boldsymbol{h})$ observed at 56 days of experiment
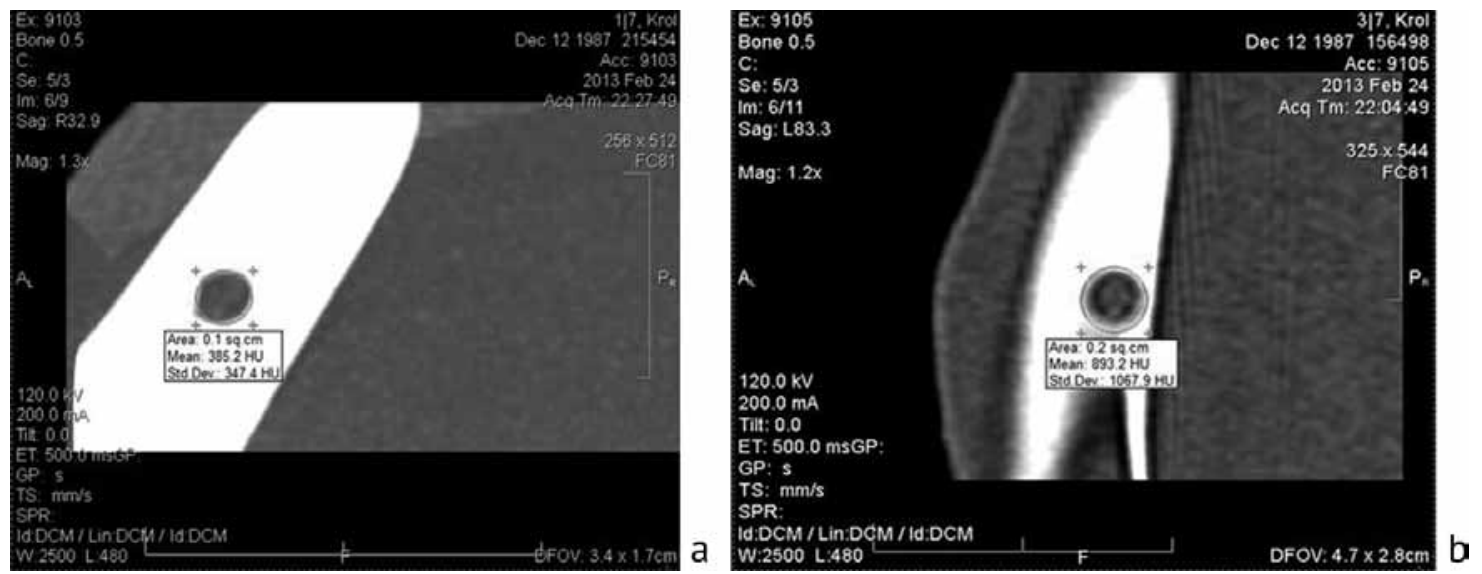

Fig. 4 CT scan of the pelvic limb of a rabbit produced at 7 days of experiment: tibial bone density measured with MPR in (a) controls, (b) experimental group 


\section{DISCUSSION}

Functional activity of osteoblasts plays a key role in bone formation through physiological and reparative regeneration. Pathological processes of different genesis (osteoporosis, trauma, etc) have a substantial effect on the rate of bone defect healing. Factors regulating osteogenic differentiation include statins, metformin, bone morphogenetic proteins -2 and -7 , parathyroid hormone, etc. [25-29]. Despite considerable differences in molecular mechanisms of action of the above factors they all have a weak point of to be persistent at the site of bone defect to achieve evident osteogenic effect. Our series assessing phosphatase activity and alizarin red staining showed for the first time that a compound could considerably stimulate osteoblast differentiation in vitro and intracellular mineralization in osteoblastic cell line MC3T3-E1. Nevertheless, INROK had no effect on osteoclast activity of RAW264.7 cells but substantially promoted bone defect healing in vivo. The preparation containing etidronates of lanthanide and calcium ions was shown to speed up healing of small bone defects in vivo. This effect could occur due to the compound stimulating osteogenic differentiation and osteoblast mineralization in vivo that was seen in experiments with MC3T3-E1 cell line. The INROK compound had no effect on osteoclast differentiation of RAW 264.7 cell line.

\section{CONCLUSION}

1. The series allowed presentation of the scientific substantiation of the possibility to activate reparative osteogenesis via the use of a preparation containing etidronates of lanthanide and calcium ions which deactivated resorption in remodeling of bone microarchitectonics at induced trauma. The compound appeared to stimulate osteoblast activity having no effect on osteoclast activity in vitro.

2. CT findings showed statistically significant differences in cortical densitometry of experimental animals at 7 days of experiment. Animals that underwent local infections of the preparation showed 2.5 -fold increase in bone restructuring at the site of osteoreparation.

3. Morphological assessment of regeneration demonstrated differences between the study groups. An area of unhealed perforation was considerably less in experimental animals than that in controls at 7 days of experiment. Bone defect was filled with enchondral regenerate bone whereas controls developed perichondral osteogenesis at 14 days of experiment.

4. Therefore, the series showed for the first time that a preparation containing etidronates of lanthanide and calcium ions (INROK) could considerably induce osteogenic differentiation of osteoblasts in vitro and promote healing of local bone defects.

5. Exploratory analysis indicated to the evident osteoblast activity of a composition of lanthanides and etidronate that can be useful in clinical practice to improve regeneration of at least small bone defects.

The authors received no financial support for the research. Authors declare that there is no apparent or potential conflict of interests regarding the publication of this article.

\section{REFERENCES}

1. Shastov A.L., Kononovich N.A., Gorbach E.N. Problema zameshcheniia posttravmaticheskikh defektov dlinnykh kostei v otechestvennoi travmatologo-ortopedicheskoi praktike(obzor literatury) [Management of posttraumatic long bone defects in the national orthopedic practice (literature review)]. Genij Ortopedii, 2018, vol. 4, no. 2, pp. 252-257. (in Russian)

2. Duncan C.P., Masri B.A. Fractures of the femur after hip replacement. Instr. Course Lect. 1995. Vol. 44. P. $293-304$.

3. Kononovich N.A., Popkov A.V. Analiz prizhiznennoi otsenki bezopasnosti ispolzovaniia implantatov s bioaktivnym napyleniem [Analysis of intravital safety assessment of using implants with bioactive spraying]. Vestnik Ulianovskoi Gosudarstvennoi Selskokhoziaistvennoi Akademii, 2018, no. 3 (43), pp. 126-132. (in Russian)

4. Robey P.G. Vertebrate mineralized matrix proteins: structure and function. Connect. Tissue Res., 1996, vol. 35, no. 1-4, pp. 131-136.

5. Kabirov G., Shakirova F., Manirambona J., Akhtyamov I., Gatina E., Tsiplakov D. Morphological Studies of Local Influence of Implants with Coatings Based on Superhard Compounds on Bone Tissue under Conditions of Induced Trauma. J. Fac. Vet. Med. Istanbul Univ., 2015, vol. 41, no. 2, pp. 177-184.

6. Ahrens L.H. Shielding efficiency of cations. Nature, 1954, vol. 174, pp. 644-645.

7. Brooker M.H., Bredig M.A. Significance of both polarizability and polarizing power of cations in nitrate vibrational spectra. J. Chem. Phys., 1973, vol. 58, pp. 5319-5327. DOI: 10.1063/1.1679146.

8. Mikenda W. IR study of cation effects on the O-D stretching frequencies of isotopically dilute HDO in aqueous salt solutions. Chemical Monthly, 1986, vol. 117, no. 8-9, pp. 977-984.

9. Schultze-Mosgau S., Keweloh M., Wiltfang I., Kessler P., Neukam F.W. Histomorphometric and densitometric changes in bone volume and structure after avascular bone grafting in the extremely atrophic maxilla. Br. J. Oral Maxillofac. Surg., 2001, vol. 39, no. 6, pp. 439-447. DOI: 10.1054/bjom.2001.0617.

10.Barta C.A., Sachs-Barrable K., Jia J., Thompson K.H., Wasan K.M., Orvig C. Lanthanide containing compounds for therapeutic care in bone resorption disorders. Dalton Trans., 2007, no. 43, pp. 5019-5030. DOI: 10.1039/b705123a. 
11.Mawani Y., Cawthray J.F., Chang S., Sachs-Barrable K., Weekes D.M., Wasan K.M., Orvig C. In vitro studies of lanthanide complexes for the treatment of osteoporosis. Dalton Trans., 2013, vol. 42, no. 17, pp. 5999-6011. DOI: 10.1039/c2dt32373g.

12.Fricker S.P. The therapeutic application of lanthanides. Chem. Soc. Rev., 2006, vol. 35, no. 6, pp. 524-533.

13.Aerssens J., Boonen S., Lowet G., Dequeker J. Interspecies differences in bone composition, density, and quality: potential implications for in vivo bone research. Endocrinology, 1998, vol. 139, no. 2, pp. 663-670.

14.Issa J.P., Bentley M.V., Iyomasa M.M., Sebald W., De Albuquerque R.F. Sustained release carriers used to delivery bone morphogenetic proteins in the bone healing process. Anat. Histol. Embryol., 2008, vol. 37, no. 3, pp. 181-187.

15.Urist M.R., Silverman B.F., Büring K., Dubuc F.L., Rosenberg J.M. The bone induction principle. Clin. Orthop. Relat. Res., 1967, vol. 53, pp. 243-283.

16.Deviatov F.V., Kholmogortsev E.G. Sposob regeneratsii kostnoi tkani v eksperimente [The way for regenerating bone tissue experimentally]. Patent RF, no. 2248210, 2003. (in Russian)

17.Deviatov F.V. Sposob regeneratsii kostnoi tkani $v$ eksperimente [The way for regenerating bone tissue experimentally]. Patent Application RF, 2012119192/14, 2012. (in Russian)

18.Deviatov F.V. Method for regenerating bone tissue. EP2848250, 2012. European Patent Bulletin, 2016, 36, pp. 723.

19.Talashova I.A., Silanteva T.A., Kononovich N.A., Luneva S.N. Biosovmestimost kaltsii-fosfatnykh materialov biogennogo proiskhozhdeniia pri implantatsii v oblast defektov kostei sobak [Biogenic calcium phosphate materials implanted into canine bone defects and their biocompatibility]. Genij Ortopedii, 2016, no. 4, pp. 95-103. (in Russian)

20.Avtandilov G.G. Meditsinskaia Morfometriia [Medical morphometry]. M., Meditsina,1990, 384 p. (in Russian)

21.Korzhevskii D.E. Kratkoe izlozhenie osnov gistologicheskoi tekhniki dlia vrachei I laborantov-gistologov [Summary of the basics of histological technique for physicians and laboratory assistants-histologists]. SPb., Krof, 2005, 48 p. (in Russian)

22.Djachkova G.V., Stepanov R.V., Korabelnikov M.A., Bojchuk S.P., Suchodolova L.V., Obanina N.F. Computertomographie zur quantitative Bewertung der reparativen Knochenneubildung. Chirurgische Allgemeine, 2007, no. 1, pp. 35-37.

23.Lee S.H., Kim J.K., Jang H.D. Genistein inhibits osteoclastic differentiation of RAW 264.7 cells via regulation of ROS production and scavenging. Int. J. Mol. Sci., 2014, vol. 15, no. 6, pp. 10605-10621. DOI: 10.3390/ijms150610605.

24.Maeda T., Matsunuma A., Kurahashi I., Yanagawa T., Yoshida H., Horiuchi N. Induction of osteoblast differentiation indices by statins in MC3T3-E1 cells. J. Cell Biochem., 2004, vol. 92, no. 3, pp. 458-471.

25.Luppen C.A., Leclerc N., Noh T., Barski A., Khokhar A., Boskey A.L., Smith E., Frenkel B. Brief bonemorphogenetic protein 2 treatment of glucocorticoid-inhibited MC3T3-E1 osteoblasts rescues commitment-associated cell cycle and mineralization without alteration of Runx2. J. Biol. Chem., 2003, vol. 278, no. 45, pp. 44995-45003.

26.Li I.W., Cheifetz S., McCulloch C.A., Sampath K.T., Sodek J. Effects of osteogenic protein-1 (OP-1, BMP-7) on bone matrix protein expression by fetal rat calvarial cells are differentiation stage specific. J. Cell Physiol., 1996, vol. 169, no. 1, pp. 115-125. DOI: 10.1002/(SICI)1097-4652(199610)169:1<115::AID-JCP12>3.0.CO;2-C.

27.Cortizo A.M., Sedlinsky C., McCarthy A.D., Blanco A., Schurman L. Osteogenic actions of the anti-diabetic drug metformin on osteoblasts in culture. Eur. J. Pharmacol., 2006, vol. 536, no. 1-2, pp. 38-46. DOI: 10.1016/j.ejphar.2006.02.030.

28.Schiller P.C., D’Ippolito G., Roos B.A., Howard G.A. Anabolic or catabolic responses of MC3T3-E1 osteoblastic cells to parathyroid hormone depend on time and duration of treatment. J. Bone Miner. Res., 1999, vol. 14, no. 9, pp. 1504-1512. DOI: 10.1359/ jbmr.1999.14.9.1504.

29.Alexy T., Baskurt O.K., Nemeth N., Uyuklu M., Wenby R.B., Meiselman H.J. Effect of lanthanides on red blood cell deformability and response to mechanical stress: role of lanthanide ionic radius. Biorheology, 2011, vol. 48, no. 3-4, pp. 173-183.

Received: 06.05.2019

\section{Information about the authors:}

1.Sergei V. Boichuk, M.D., Ph.D., Professor,

Kazan State Medical University, Kazan, Russian Federation,

Email: boichuksergei@mail.ru

2. Elena A. Zhitlova,

Kazan State Academy of Veterinary Medicine, Kazan, Russian Federation,

Email: zhitlowa.elena@yandex.ru

3. Faina V. Shakirova, Ph.D. of Veterinarian Sciences, Professor,

Kazan State Academy of Veterinary Medicine, Kazan, Russian Federation,

Email: shakirova-fv@yandex.ru

4.Dmitrii E. Tsyplakov, M.D., Ph.D., Professor,

Kazan State Medical University, Kazan, Russian Federation,

Email: dr-allakazan@ya.ru

5.Ildar F. Akhtiamov, M.D., Ph.D., Professor,

Kazan State Medical University, Kazan, Russian Federation,

Email: yalta60@mail.ru

6. Fedor V. Deviatov, Ph.D. of Chemical Sciences, Professor,

Kazan Federal University, Kazan, Russian Federation,

Email: feddev54@gmail.com

7. Bulat R. Ramazanov,

Kazan State Medical University, Kazan, Russian Federation,

Email: bulatramazan@mail.ru

8. Rustem Kh. Zakirov,

Kazan State Medical University, Kazan, Russian Federation,

Email: Metsur@yandex.ru 